\title{
Immune System Control of Rat and Rabbit Colonic Electrolyte Transport Role of Prostaglandins and Enteric Nervous System
}

\author{
M. Jonathan Bern, Christopher W. Sturbaum, S. Selim Karayalcin, Helen M. Berschneider, \\ Joseph T. Wachsman, and Don W. Powell \\ Department of Medicine and Core Center in Diarrheal Diseases, University of North Carolina at Chapel Hill, \\ Chapel Hill, North Carolina 27599
}

\begin{abstract}
The role of the immune system in controlling intestinal electrolyte transport was studied in rat and rabbit colon in Ussing chambers. A phagocyte stimulus, the chemotactic peptide FMLP, and a mast cell stimulus, sheep anti-rat IgE, caused a brief ( $<10 \mathrm{~min}$ ) increase in short-circuit current (Isc). Products of immune system activation, platelet-activating factor (PAF) and reactive oxygen species (ROS), caused a sustained, biphasic increase in the Isc. Ion replacement and flux studies indicated that these agonists stimulated electrogenic $\mathrm{Cl}$ secretion and inhibited neutral $\mathrm{NaCl}$ absorption; responses that were variably inhibited by the cyclooxygenase blockers indomethacin and piroxicam. Lesser degrees of inhibition by nordihydroguaiaretic acid could be accounted for by decreased prostaglandin synthesis rather than by lipoxygenase blockade. Tetrodotoxin, hexamethonium, and atropine also inhibited immune agonist-stimulated Isc, but had no effect on immune agonist-stimulated production of $\mathrm{PGE}_{2}$ or $\mathrm{PGI}_{2}$. These results indicate that immune system agonists alter intestinal epithelial electrolyte transport through release of cyclooxygenase products from cells in the lamina propria with at least $50 \%$ of the response being due to cyclooxygenase product activation of the enteric nervous system. The immune system, like the enteric nervous system and the endocrine system, may be a major regulating system for intestinal water and electrolyte transport in health and disease.
\end{abstract}

\section{Introduction}

AA metabolites of both the cyclooxygenase and lipoxygenase pathway are thought to play a role in the diarrheas of intestinal inflammation $(1,2)$ and intestinal anaphylaxis (3). Elevated levels of AA metabolites have been demonstrated in both natural diseases and experimental disease models and these products can be shown to stimulate intestinal $\mathrm{Cl}$ and water secretion and inhibit intestinal $\mathrm{NaCl}$ and water absorption (4-6). Recently, our laboratory $(7)$ and others $(8,9)$ have shown fairly conclusively that the major source of eicosanoids in the intes-

This study was presented in part at the 1987 and 1988 Annual Meetings of the American Gastroenterological Association and has appeared in abstract form (1987. Gastroenterology. 92:1314 [Abstr.] and 1988. Gastroenterology. 94:A217 [Abstr.]).

Address reprint requests to Dr. D. W. Powell, CB \#7080, 326 Burnett-Womack Bldg., University of North Carolina, Chapel Hill, NC 27599-7080.

Received for publication 22 August 1988 and in revised form 8 December 1988.

J. Clin. Invest.

(c) The American Society for Clinical Investigation, Inc.

$0021-9738 / 89 / 06 / 1810 / 11 \quad \$ 2.00$

Volume 83, June 1989, 1810-1820 tine, particularly prostaglandins, is the subepithelial region of the gut. An important component of the lamina propria and submucosa are immune cells, including lymphocytes, phagocytes (macrophages, neutrophils, and eosinophils) and mast cells. Phagocytes and mast cells, in particular, are known to be avid producers of eicosanoids $(10,11)$. Therefore, stimulants of the immune system as well as products of immune cell stimulation might play important roles in intestinal secretion of inflammation and anaphylaxis through the release of eicosanoids in the lamina propria with subsequent stimulation of the enterocyte. We undertook studies of both immune cell stimulants such as the chemotactic peptide FMLP, which is thought to be specific for phagocytic cells, and anti-rat IgE immunoglobulin, which is a potent, but not entirely specific stimulus of mast cells. Similarly, we studied the transport effects of immune cell products such as reactive oxygen species (ROS), ${ }^{1}$ which are released by phagocytes during the respiratory burst, and platelet-activating factor (PAF; 1-alkyl-2acetyl-sn-glycero-3-phosphocholine), a lipid mediator released by both phagocytes and mast cells. The results reported here implicate the immune system as a regulator of intestinal electrolyte transport through a complex interaction with the enteric nervous system and the epithelium.

\section{Methods}

Transport studies. Male Sprague-Dawley rats weighing 375-500 g were killed by cervical dislocation. Male New Zealand rabbits weighing 3-4 $\mathrm{kg}$ were killed with intravenous pentobarbital sodium $(60 \mathrm{mg} / \mathrm{kg})$. The colon of each animal was removed, opened longitudinally, and washed of contents with oxygenated Ringer's solution. The entire rat colon or a 5-cm segment of distal rabbit colon was stripped of its outer muscle layers with a combination of blunt and sharp dissection as previously described (12-14), taking care that the submucosal plexus of the enteric nervous system remained intact as confirmed by histology.

Segments of colon were mounted in lucite half chambers with $0.5-\mathrm{cm}^{2}$ apertures, each side containing 5-10 $\mathrm{ml}$ Ringer's solution. The Ringer's solution was maintained at $37^{\circ} \mathrm{C}$ and $\mathrm{pH} 7.4$ and was gassed with $95 \% \mathrm{O}_{2} / 5 \% \mathrm{CO}_{2}$. It contained (in millimolar): $\mathrm{Na}, 140 ; \mathrm{K}, 5.2$; $\mathrm{Ca}, 1.2 ; \mathrm{Mg}, 1.2 ; \mathrm{Cl}, 119.8 ; \mathrm{HCO}_{3}, 25 ; \mathrm{H}_{2} \mathrm{PO}_{4}, 0.4 ; \mathrm{HPO}_{4}, 2.4$; and glucose, 10 . In some studies, $\mathrm{Cl}$-free and $\mathrm{Cl}-\mathrm{HCO}_{3}$-free solutions were made by replacing $\mathrm{Cl}$ and $\mathrm{HCO}_{3}$ with isethionate. When $\mathrm{HCO}_{3}$ was omitted, the solutions were oxygenated with $100 \% \mathrm{O}_{2}$. The bathing solutions were connected via agar bridges to calomel electrodes in

1. Abbreviations used in this paper: $\mathrm{ACh}$, acetylcholine; anti-IgE, sheep anti-rat IgE; ATR, atropine; DPH, diphenhydramine; G, conductance; HEX, hexamethonium; Isc, short-circuit current; INDO, indomethacin; $J$, flux; $J_{\text {net }}{ }^{\mathrm{R}}, I \mathrm{sc}-\left(J_{\text {net }}{ }^{\mathrm{Na}}-J_{\text {net }}{ }^{\mathrm{Cl}}\right)$; MLP, methionyl-leucylphenylalanine; ms, mucosal-to-serosal; NDGA, nordihydroguaiaretic acid; PAF, platelet-activating factor; PXM, piroxicam; PD, potential difference; ROS, reactive oxygen species; sm, serosal-to-mucosal; TTX, tetrodotoxin; VIP, vasoactive intestinal polypeptide; $\mathrm{X}$, xanthine; XO, xanthine oxidase. 
order to measure the electrical potential difference (PD) across the epithelial-submucosal preparation. The tissues were short-circuited to zero PD by an automatic voltage clamp (World Precision Instruments, Inc., New Haven, $\mathrm{CT}$ ) using $\mathrm{Ag}-\mathrm{AgCl}$ electrodes connected to the bathing solution via agar bridges. Tissues were continuously short-circuited except for 5-s intervals every 15-30 min when the open-circuit $P D$ was read. Conductances $(G)$ were calculated from the open-circuit PD and the short circuit current (Isc) using Ohm's law. Unidirectional $\mathrm{Na}$ and $\mathrm{Cl}$ fluxes were measured in paired tissues which had electrical conductances differing by no more than $25 \%$. Flux measurements were accomplished by the addition of ${ }^{22} \mathrm{Na}$ and ${ }^{36} \mathrm{Cl}$ to opposite sides of paired tissues (15). All fluxes were measured in the steady state.

Agonists were added to the serosal bathing solution after stabilization of the tissues either in Ringer's solution (control) or after the serosal addition of various AA metabolism or neural antagonists/inhibitors. At least 15 min of preincubation with inhibitors was allowed before adding the various agonists. Drug concentration-response curves were obtained by adding the various agonists to the serosal solution of four to eight tissues mounted from a single animal. Two methods were used to measure the response to agonists: $(a)$ an integrated response (area under the response curve) and (b) the maximal change in $I s c$ above baseline $\left(\Delta I \mathrm{sc}_{\mathrm{MAX}}\right)$ at 3-6 min after agonist (peak 1) and, if the response was biphasic, at the peak of the second response (15 min for PAF and $30 \mathrm{~min}$ for ROS). Because both methods gave essentially the same results, the $\Delta I \mathrm{Is}_{\mathrm{MAx}}$ was used. In experiments involving inhibitors, tissues pretreated with inhibitor were compared with simultaneously studied control tissues from the same animal. At varying intervals after the addition of inhibitors, antagonists, or agonists, $1-\mathrm{ml}$ samples were removed from the serosal bathing solutions, placed in plastic vials, gassed with argon and stored at $-20^{\circ} \mathrm{C}$ to await RIA of various eicosanoids. Tissues were removed from the Ussing chambers, fixed with buffered $4 \%$ formaldehyde- $10 \%$ gluteraldehyde and stained with hematoxylin and eosin or with diamine silver for histological assessment of epithelial and neural integrity, respectively.

Prostaglandin assays. $\mathrm{PGE}_{2}$ and 6 keto $\mathrm{PGF}_{1 \alpha}$ content of incubation solutions was determined by direct immunoassay on 100-300- $\mu$ samples according to the method of Granstrom and Kindahi (16). The PG antisera had minimal cross-reactivity $(<1 \%$ for most other prostaglandins) except for $6 \%$ cross-reactivity of the $\mathrm{E}_{2}$ antisera for $\mathrm{PGA}_{2}$ and 2-8\% cross-reactivity of the 6 keto $\mathrm{PGF}_{1 \alpha}$ antisera for $\mathrm{PGF}_{1 \alpha}$ and $\mathrm{PGF}_{2 \alpha}$. The accuracy and precision of the assays was determined under each experimental condition. Standard curves were assayed in the presence of the various inhibitors and agonists that were used in the study. It was found that indomethacin (INDO) and piroxicam (PXM) reproducibly shifted the standard curve for $\mathrm{PGE}_{2}$, whereas tetrodotoxin (TTX) and hexamethonium (HEX) had a similar effect on the assay for 6 keto $\mathrm{PGF}_{1 \alpha}$. Therefore, in studies where these inhibitors were in the experimental samples, standards were used that contained the proper inhibitor. Among the agonists, PAF $\left(10^{-5} \mathrm{M}\right)$ was found to interfere with the prostaglandin assays. However, when a known amount of prostaglandin standard was added to solutions in which PAF had been previously incubated with intestinal tissue, no interference could be detected. It is likely that PAF, which is avidly bound by protein (17), became bound to tissue or albumin in the Ussing chamber and, thus, was not available for interference with the immunoassay. All assays were further checked by monitoring parallelism (linearity with sample size): As previously described, such techniques give valid assays for $\mathrm{PGE}_{2}$ and 6 keto $\mathrm{PGF}_{1 \alpha}$ as checked by HPLC (7).

Prostaglandin production was calculated from the concentrations measured at successive 15 -min periods. Reported values represent the average production in the first two 15 -min periods except in the rabbit, where prostaglandin production by FMLP was only stimulated for the first $15 \mathrm{~min}$. All values were expressed as $\mathrm{ng} / 30 \mathrm{~min}$ per $\mathrm{cm}^{2}$.

Materials. All chemicals and whole sheep sera were obtained from Sigma Chemical Co. (St. Louis, MO.) ${ }^{22} \mathrm{Na}$ and ${ }^{36} \mathrm{Cl}$ were obtained from Amersham Corp. (Arlington Heights, IL) and ICN Radiochemicals (Irving, CA), respectively. Sheep anti-rat IgE was purchased from ICN Immunobiologicals (Lisle, IL). RIA reagents for $\mathrm{PGE}_{2}$ and for
6-Keto $\mathrm{PGF}_{1 \alpha}$ were obtained from Advanced Magnetics, Inc., (Cambridge, MA).

Methionyl-leucyl-phenylalanine (MLP) and FMLP were dissolved in DMSO, divided into aliquots, stored at $-20^{\circ} \mathrm{C}$ and then thawed just before addition to the Ussing chambers. Lyophilized globulin or sera were reconstituted with sterile water, divided into aliquots and stored at $4^{\circ} \mathrm{C}$. L- $\alpha$-Lysophatidylcholine, $\gamma$-o-hexadecyl (lyso PAF) and L- $\alpha$ phosphatidylcholine, $\beta$-acetyl- $\gamma$ - $\alpha$-hexadecyl (PAF) were obtained as dry powder, dissolved in $2.5 \%$ BSA in water and were stored in aliquots at $-20^{\circ} \mathrm{C}$ for single time use. ROS were created in the Ussing chamber by adding varying concentrations of xanthine oxidase (XO) to $0.7 \mathrm{mM}$ xanthine $(X)$ in the serosal solution. INDO, PXM, and nordihydroguaiaretic acid (NDGA) were dissolved as stock solutions in DMSO. All reagents dissolved in DMSO were prepared so that no more than 10 $\mu \mathrm{l}$ was added to $10 \mathrm{ml}$ of bathing solution in the Ussing chambers. DMSO at $0.1 \%$ concentrations does not have any effect on electrolyte transport by intestine. TTX, HEX, and atropine (ATR) were dissolved in Ringer's solution.

Statistical evaluation. If more than one study was done on the same intestine, the responses were averaged to give a single value for that animal. Hence, in the data presented here, $n$ equals the number of animals. The studies were always carried out in paired fashion so that an agonist or antagonist/inhibitor could be compared with simultaneous control tissue from the same animal. To determine statistical significance, we used either the paired $t$ test or, if multiple comparisons were undertaken, a parametric or nonparametric analysis of variance was used.

\section{Results}

Colonic transport response to immune system agonists. Figs. 1-5 depict the electrical response $(\Delta I \mathrm{sc})$ of rat and rabbit colon to the immune system stimuli and products. The concentration responses to these agonists are also shown on the appropriate graph. Two patterns of response were observed: a monophasic, transient response to immune cell stimuli and a biphasic, sustained response to immune cell products. Anti-rat IgE (Fig. 1) and FMLP (Fig. 2 and 3) caused a brief, but significant increase in Isc that peaked at 4-6 $\mathrm{min}$ and was essentially

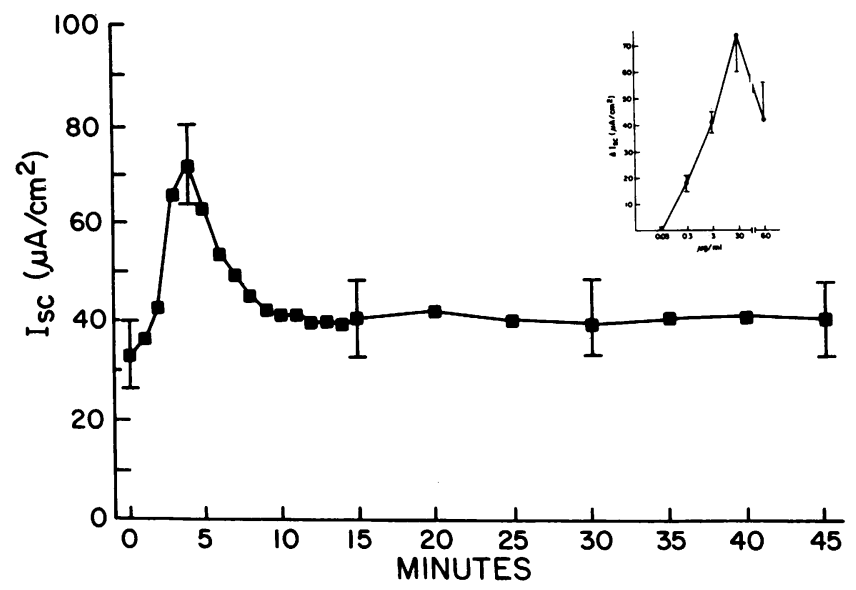

Figure 1. Short-circuit current response to sheep anti-rat IgE (3 $\mu \mathrm{g} / \mathrm{ml}$ added to the serosal bathing solution of the Ussing chambered-rat colon $(n=6)$. (Inset) The concentration-response curve. The $\mathrm{ED}_{s 0}$ to anti-IgE was $2.7 \mu \mathrm{g} / \mathrm{ml}$ and the maximal change in $I \mathrm{sc}$ with $30 \mu \mathrm{g} / \mathrm{ml}$ was $74 \mu \mathrm{A} / \mathrm{cm}^{2}$. The apparent elevation above baseline of the Isc at 10-45 min was not confirmed at other concentrations or in subsequent studies at $3 \mu \mathrm{g} / \mathrm{ml}$. There was no short-circuit current response to whole sheep serum, which was used as a control (not shown). 


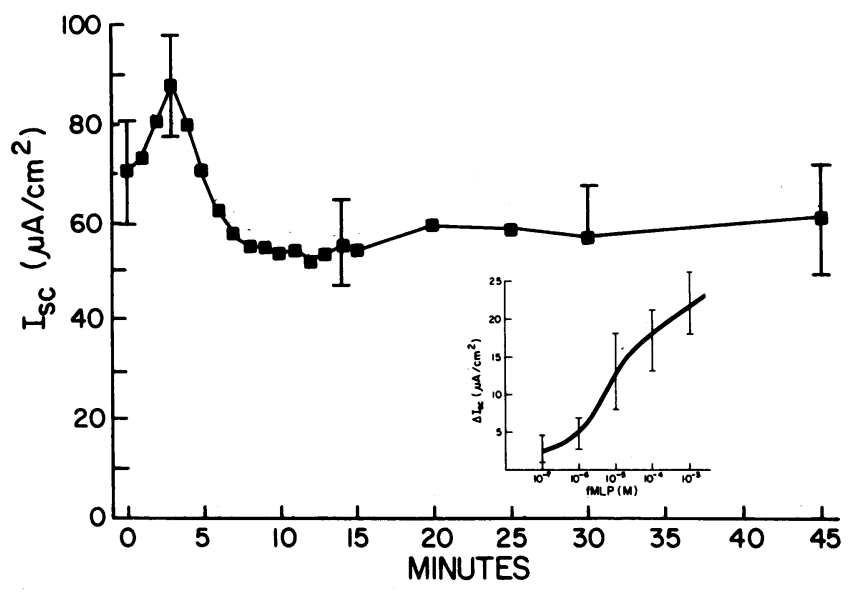

Figure 2. Isc response to FMLP $(0.1 \mathrm{mM})$ in Ussing chambered-rat colon $(n=6)$. The concentration-response curve shows an $\mathrm{ED}_{50}$ of $\sim 8 \times 10^{-6} \mathrm{M}$ and an $\Delta I \mathrm{sc}_{\mathrm{MAX}}$ of $\sim 22 \pm 4 \mu \mathrm{A} / \mathrm{cm}^{2}$. The apparent suppression of Isc at 10-45 min was not confirmed in subsequent studies. The nonformylated tripeptide MLP was used as a control and in concentrations up to $1 \mathrm{mM}$ had no effect on the Isc (not shown).

completed by $10 \mathrm{~min}$. The concentration response to anti-IgE was similar (maximal response $3-30 \mu \mathrm{g} / \mathrm{ml}$ ) to that reported for eicosanoid secretion by isolated human intestinal mast cells (18). However, the concentration of FMLP $(>0.1 \mathrm{mM})$ necessary for substantial stimulation of the Isc in the rat colon far exceeded the concentration necessary to stimulate the phagocytic cells of most other species (19). In addition, on occasion, the rat colon of an individual animal did not respond to FMLP at all. However, it is known that rat phagocytes contain a paucity of FMLP receptors. Therefore, we repeated these experiments with rabbit colon, a species with $\sim 10^{5}$ receptors/neutrophil. In rabbit colon (Fig. 3), not only was there a consistent response to much lower levels of FMLP (10 nM) but, the response was also significantly greater; $\Delta I \mathrm{Sc}_{\mathrm{MAX}}$ of 92 $\mu \mathrm{A} / \mathrm{cm}^{2}$ as compared with $22 \mu \mathrm{A} / \mathrm{cm}^{2}$ in the rat. Furthermore, the $\mathrm{ED}_{50}$ response for the rabbit was $\sim 3 \mathrm{nM}$, which is similar to that reported for FMLP degranulation of rabbit neutrophils

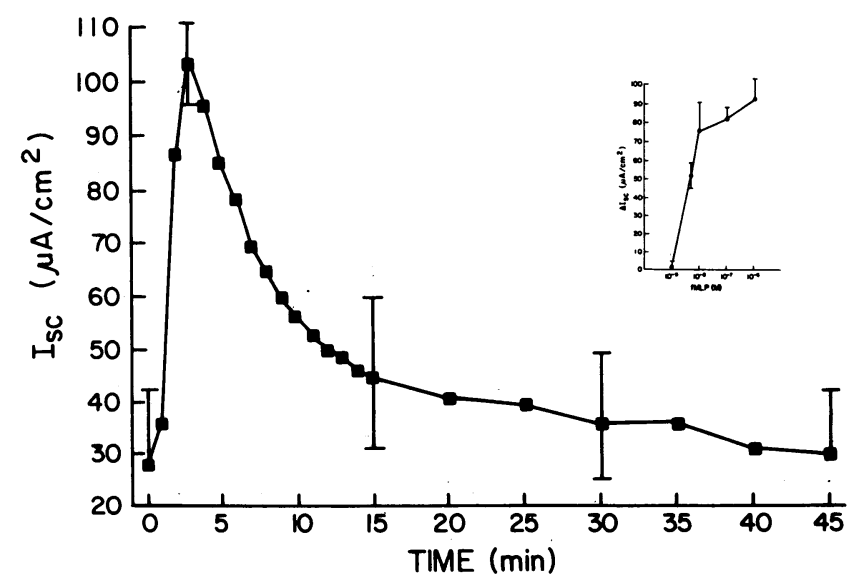

Figure 3. Isc response of rabbit colon to FMLP $(10 \mathrm{nM}, n=6)$. The concentration response curve in the inset shows an $\mathrm{ED}_{50}$ in rabbit colon of $3 \mathrm{nM}$ and a $\Delta I \mathrm{Isc}_{\mathrm{MAX}}$ of $92 \mu \mathrm{A} / \mathrm{cm}^{2}$.

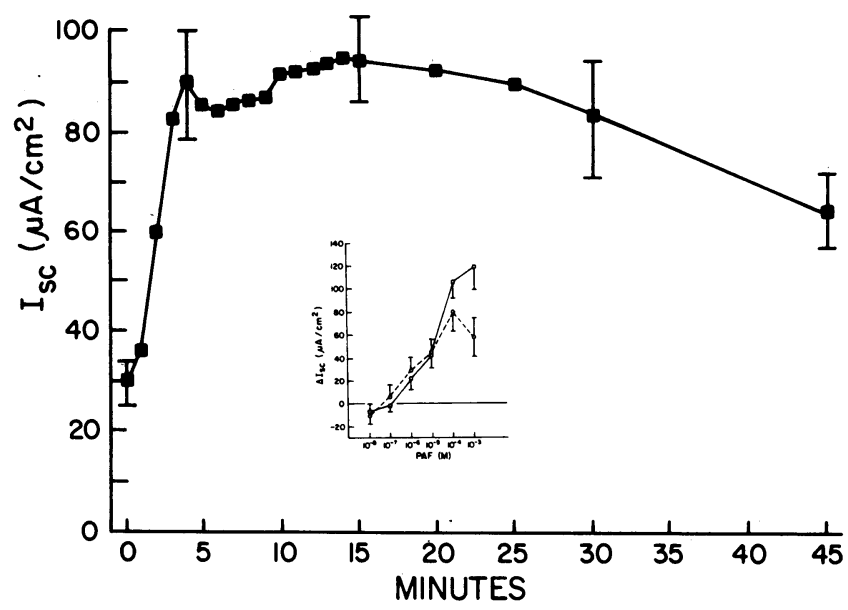

Figure 4. Isc response of the rat colon to $\operatorname{PAF}(10 \mu \mathrm{M}, n=6)$. Note the biphasic response to PAF with an initial peak at $\sim 4$ min and a delayed $\Delta I$ sc peak at $\sim 15 \mathrm{~min}$. The concentration-response curve revealed an $\mathrm{ED}_{50}$ of $20 \mu \mathrm{M}$ and a $\Delta I \mathrm{sc}_{\mathrm{MAx}}$ of $110 \pm 25 \mu \mathrm{A} / \mathrm{cm}^{2}$ for peak $1(-)$ and $80 \pm 14 \mu \mathrm{A} / \mathrm{cm}^{2}$ for peak $2(-----)$. LysoPAF was used as a control and in concentrations up to $1 \mathrm{mM}$ had no effect on Isc (not shown).

(19). Our findings with FMLP resemble those reported in preliminary studies by others (20).

In contrast to the immune system stimuli, the immune cell products PAF and ROS (created by the X/XO reaction) both demonstrated a biphasic response (Figs. 4 and 5) with an initial peak at 3-6 min followed by a second Isc peak at $\sim 15 \mathrm{~min}$ for $\mathrm{PAF}$ and $30-40 \mathrm{~min}$ for $\mathrm{X} / \mathrm{XO}$. The $\mathrm{ED}_{50}$ for PAF stimulation of rat colon was $20 \mu \mathrm{M}$, similar to that obtained in rabbit colon ( $5 \mu \mathrm{M}, n=3$, not shown). This is considerably greater than that necessary to stimulate chemotaxis and degranulation of phagocytes (0.01-100 nM) (20). A distinct circadian response was noted with PAF as has been noted by others in studies of rat small intestine (21). Animals studied in the afternoon had

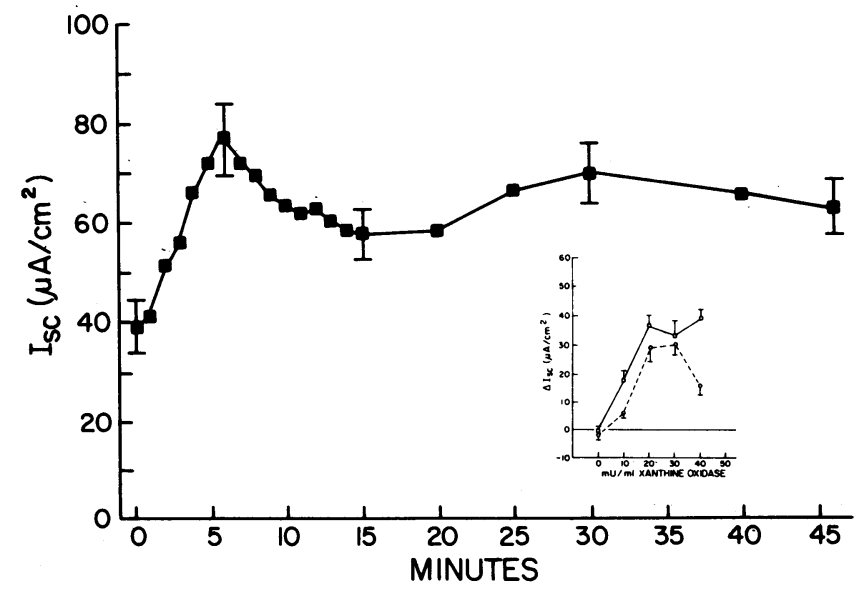

Figure 5. Isc response of rat colon to reactive oxygen metabolites created by the $\mathrm{X}(0.7 \mathrm{mM}) / \mathrm{XO}(20.8 \mathrm{mU} / \mathrm{ml})$ reaction $(n=5)$. Note the biphasic response with the initial peak at $\sim 6 \mathrm{~min}$ and a delayed peak at $30 \mathrm{~min}$. The concentration response curve demonstrates an $\mathrm{ED}_{50}$ for $\mathrm{XO}$ of $10-13 \mathrm{mU} / \mathrm{ml}$ when added to $0.7 \mathrm{mM} \mathrm{X}$. The $\Delta I \mathrm{sc}-$ MAX were $38 \pm 5$ and $30 \pm 6 \mu \mathrm{A} / \mathrm{cm}^{2}$ for peaks $1(-)$ and $2(-.---)$, respectively. The separate addition of $\mathrm{X}$ or of $\mathrm{XO}$ alone had no effect on Isc (not shown). 


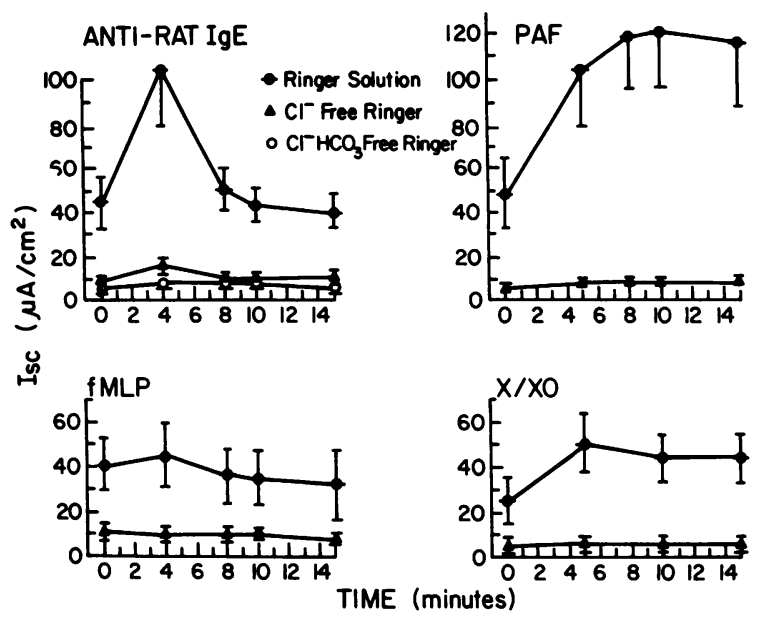

Figure 6. The Isc response to various immune cell stimulants (antirat IgE and FMLP) and immune cell products (PAF and ROS created by the $\mathrm{X} / \mathrm{XO}$ reaction) in the rat colon $(n=6)$ bathed in either Ringer's solution or $\mathrm{Cl}$-free and $\mathrm{Cl}-\mathrm{HCO}_{3}$-free Ringer's solutions. The Isc response to FMLP, PAF, and X/XO were abolished in Clfree solutions, whereas it requires removal of both $\mathrm{Cl}$ and $\mathrm{HCO}_{3}$ to abolish the Isc response to anti-rat IgE. Note also the dependence of basal Isc in the rat colon on the presence of $\mathrm{Cl}$.

blunted or absent Isc responses and were not included in the data reported here. There is no clear way to compare the concentration response to $\mathrm{X} / \mathrm{XO}$. However, as we have shown in preliminary studies, the maximum response to $\mathrm{X} / \mathrm{XO}$ is equivalent to that produced by $1 \mathrm{mM} \mathrm{H}_{2} \mathrm{O}_{2}$ (22).

Fig. 6 demonstrates that the $\Delta I$ sc's to these various agonists were essentially abolished when the studies were repeated in Cl-free Ringer's solution. The small Isc response to anti-rat IgE in Cl-free Ringer's was completely abolished when experiments were repeated in solutions free of $\mathrm{HCO}_{3}$ as well as $\mathrm{Cl}$. Fig. 6 also demonstrates that the basal Isc of rat colon is $\mathrm{Cl}$ dependent, probably representing some level of basal electrogenic $\mathrm{Cl}$ secretion.
The effect of anti-IgE on $\mathrm{Na}$ and $\mathrm{Cl}$ fluxes are shown in Table I (section $A$ ). Because the response to anti-IgE was short lived, steady-state fluxes could only be determined after the Isc had returned to baseline levels. Nonetheless, when fluxes were measured even after the anti-IgE-induced Isc response (electrogenic $\mathrm{Cl}$ secretion) was dissipated, a significant alteration in $\mathrm{Na}$ and $\mathrm{Cl}$ transport could be demonstrated, (decreased $J_{\mathrm{ms}}{ }^{\mathrm{Na}}$, $J_{\mathrm{Net}}{ }^{\mathrm{Na}}, J_{\mathrm{ms}}{ }^{\mathrm{Cl}}$, and $J_{\mathrm{Net}}{ }^{\mathrm{Cl}}$ ).

In contrast, the sustained Isc response of $\mathrm{X} / \mathrm{XO}$ allowed flux measurements during the increase in Isc. As shown in Tables II (section A) and III (section A), there was a significant decrease in $J_{\mathrm{ms}}{ }^{\mathrm{Na}}$ and $J_{\mathrm{ms}}{ }^{\mathrm{Cl}}$, as well as (in Table III [section A]) a significant increase in $J_{\mathrm{sm}}{ }^{\mathrm{Cl}}$ and Isc. The net result of these changes in unidirectional fluxes was an inhibition of $\mathrm{Na}$ and $\mathrm{Cl}$ absorption (decreased $J_{\mathrm{Net}}{ }^{\mathrm{Na}}$ and $J_{\mathrm{Net}}{ }^{\mathrm{C}}$ ) and, depending on the magnitude of the decrease in $J_{\mathrm{ms}}{ }^{\mathrm{Cl}}$ and the increase in $J_{\mathrm{sm}}{ }^{\mathrm{Cl}}$ there was either complete inhibition of net $\mathrm{Cl}$ absorption (Table II [section A]) or significant net $\mathrm{Cl}$ secretion (Table III [section A]). Together, these three tables demonstrate that the response to immune cell stimuli and products was one of inhibition of neutral $\mathrm{NaCl}$ absorption and a variable degree and duration of stimulation of electrogenic $\mathrm{Cl}$ secretion.

Inhibition of immune system-mediated colonic electrolyte transport. Because these immune cell stimulants and products are known to release eicosanoids from white blood cells and from other mesenchymal tissues, we investigated the effect of cyclooxygenase and lipoxygenase inhibitors on electrolyte transport. Table IV compares the $\Delta I I_{\mathrm{sc}} \mathrm{MAX}$ of these four immune system agonists in the presence of a cyclooxygenase blocker, INDO $\left(10^{-6} \mathrm{M}\right)$, a lipoxygenase blocker, NDGA $\left(10^{-6}\right.$ $M$ ), and to the combination of INDO and NDGA with the inhibitor responses normalized to the percent of control response. Preincubation with INDO significantly inhibited the $\Delta I \mathrm{sc}_{\mathrm{MAX}}$ to these four agonists by $\sim 60-90 \%$. There was a smaller and not always significant inhibition of the $\Delta I \mathrm{sc}_{\mathrm{MAX}}$ by NDGA $(\sim 50 \%)$. Except in the studies of rat colon with FMLP, the combination of INDO plus NDGA did not inhibit the $\Delta I$ sc to a greater extent than did INDO alone.

Table I. Effect of (A) Sheep Anti-Rat IgE (3 $\mu \mathrm{g} / \mathrm{ml})$ on Rat Colonic Electrolyte Transport and (B) Response to INDO $\left(10^{-6} \mathrm{M}\right)(n=8)$

\begin{tabular}{|c|c|c|c|c|c|c|c|c|c|c|}
\hline & $J_{\mathrm{ma}}^{\mathrm{Na}}$ & $J_{\mathrm{m}}^{\mathrm{Na}}$ & $J_{\mathrm{net}}^{\mathrm{Na}}$ & $J_{\mathrm{ms}}^{\mathrm{a}}$ & $J_{\mathrm{m}}^{\mathrm{a}}$ & $J_{\mathrm{net}}^{\mathrm{a}}$ & Isc & $J_{\text {net }}^{\mathbf{R}}$ & PD & G \\
\hline & \multicolumn{8}{|c|}{$\mu e q / h$ per $\mathrm{cm}^{2}$} & $m V$ & $\mathrm{mS} / \mathrm{cm}^{2}$ \\
\hline \multicolumn{11}{|l|}{$A$} \\
\hline (i) Basal & $18.1 \pm 0.8$ & $9.2 \pm 0.9$ & $8.9 \pm 0.7$ & $22.7 \pm 0.6$ & $14.2 \pm 0.8$ & $8.5 \pm 1.0$ & $1.3 \pm 0.1$ & $0.9 \pm 0.4$ & $-1.9 \pm 0.3$ & $20.3 \pm 2.5$ \\
\hline (ii) Anti-Rat IgE & $16.3 \pm 0.6$ & $9.6 \pm 1.2$ & $6.6 \pm 0.9$ & $19.9 \pm 0.5$ & $13.7 \pm 0.9$ & $6.2 \pm 0.7$ & $1.4 \pm 0.2$ & $1.0 \pm 0.4$ & $-2.0 \pm 0.4$ & $23.4 \pm 3.6$ \\
\hline (ii vs. $i$ ) & $P<0.05$ & NS & 0.05 & 0.01 & NS & 0.05 & NS & NS & NS & NS \\
\hline \multicolumn{11}{|l|}{$B$} \\
\hline $\begin{array}{l}\text { (iii) INDO } \\
\text { (iv) INDO }\end{array}$ & $18.9 \pm 0.7$ & $10.9 \pm 0.9$ & $8.0 \pm 0.5$ & $24.3 \pm 0.9$ & $16.7 \pm 1.0$ & $7.6 \pm 0.6$ & $0.8 \pm 1.0$ & $0.5 \pm 0.3$ & $-1.0 \pm 0.1$ & $21.2 \pm 2.1$ \\
\hline + anti-Rat IgE & $17.1 \pm 0.7$ & $11.2 \pm 1.2$ & $5.9 \pm 0.9$ & $21.7 \pm 0.8$ & $15.3 \pm 1.1$ & $6.4 \pm 0.7$ & $0.8 \pm 0.1$ & $1.3 \pm 0.5$ & $-1.1 \pm 0.1$ & $22.0 \pm 2.4$ \\
\hline (iv vs. $i i i)$ & $P<0.01$ & NS & 0.05 & 0.001 & 0.05 & 0.05 & NS & NS & NS & NS \\
\hline (iii vs. $i$ ) & $P<\mathrm{NS}$ & NS & NS & 0.05 & 0.05 & NS & 0.01 & NS & 0.01 & NS \\
\hline (iv vs. $i i)$ & $P<\mathrm{NS}$ & NS & NS & NS & NS & NS & 0.01 & NS & 0.01 & NS \\
\hline
\end{tabular}

Four pairs of tissue for each animal were studied simultaneously. Two pairs had INDO in the Ringer's solution. After a basal measurement (mean of two 15-min flux periods), the agonist (anti-rat IgE) was added to the serosal solution. After a 15-min equilibration, two additional flux periods were measured and meaned. $(i i$ vs. $i)=$ response of control colon to agonist; ( $i v$ vs. $i i i)=$ response of the inhibitor- (INDO) treated colon to the agonist; (iii vs. $i$ ) = response of the control colon to the inhibitor (INDO); (iv vs. $i i)=$ effect of the inhibitor (INDO) on the agonist response. 
Table II. Effect of (A) ROS Created by the X $(0.7 \mathrm{mM}) / \mathrm{XO}(20.8 \mathrm{mU} / \mathrm{ml})$ Reaction on Rat Colonic Electrolyte Transport and $(B)$ Response to INDO $\left(10^{-6} \mathrm{M}\right)(n=8)^{*}$

\begin{tabular}{|c|c|c|c|c|c|c|c|c|c|c|}
\hline & $J_{\operatorname{ma}}^{\mathrm{Na}}$ & $J_{\mathrm{m} m}^{\mathrm{Na}}$ & $J_{\mathrm{net}}^{\mathrm{Na}}$ & $J_{\mathrm{ma}}^{\mathrm{a}}$ & $J_{\mathrm{m}}^{\mathrm{a}}$ & $J_{\text {net }}^{a}$ & Isc & $J_{\mathrm{Det}}^{\mathbf{R}}$ & PD & $\mathbf{G}$ \\
\hline & \multicolumn{8}{|c|}{$\mu e q / h_{p e r} \mathrm{~cm}^{2}$} & $m V$ & $\mathrm{mS} / \mathrm{cm}^{2}$ \\
\hline \multicolumn{11}{|l|}{$A$} \\
\hline (i) Basal & $17.8 \pm 1.3$ & $11.3 \pm 1.0$ & $6.5 \pm 1.3$ & $22.4 \pm 1.5$ & $15.9 \pm 1.1$ & $6.4 \pm 1.4$ & $1.1 \pm 0.1$ & $1.1 \pm 0.5$ & $-1.5 \pm 0.2$ & $20.0 \pm 2.3$ \\
\hline (ii) $\mathrm{X} / \mathrm{XO}$ & $15.1 \pm 0.8$ & $13.1 \pm 0.8$ & $1.9 \pm 0.8$ & $17.6 \pm 0.7$ & $17.6 \pm 1.0$ & $0.0 \pm 0.8$ & $2.2 \pm 0.2$ & $0.3 \pm 0.5$ & $-2.5 \pm 0.4$ & $26.6 \pm 2.7$ \\
\hline (ii vs. $i)$ & $P<0.05$ & 0.05 & 0.01 & 0.01 & NS & 0.001 & 0.001 & 0.05 & 0.05 & 0.01 \\
\hline \multicolumn{11}{|l|}{ B } \\
\hline (iii) INDO & $16.7 \pm 0.7$ & $10.2 \pm 0.4$ & $6.4 \pm 0.6$ & $22.1 \pm 1.5$ & $15.9 \pm 1.1$ & $6.2 \pm 0.8$ & $0.7 \pm 0.1$ & $0.4 \pm 0.6$ & $-0.9 \pm 0.2$ & $20.4 \pm 1.5$ \\
\hline (iv) INDO + X/XO & $15.4 \pm 0.6$ & $10.6 \pm 0.7$ & $4.8 \pm 0.9$ & $19.7 \pm 1.3$ & $15.3 \pm 1.2$ & $4.4 \pm 0.6$ & $1.1 \pm 0.2$ & $0.7 \pm 0.5$ & $-1.5 \pm 0.3$ & $21.3 \pm 2.5$ \\
\hline (iv vs. iii) & $P<0.05$ & NS & 0.05 & 0.001 & NS & 0.05 & 0.01 & NS & 0.01 & NS \\
\hline (iii vs. $i$ ) & $P<\mathrm{NS}$ & NS & NS & NS & NS & NS & 0.05 & NS & 0.05 & NS \\
\hline (iv vs. $i i)$ & $P<\mathrm{NS}$ & 0.001 & 0.05 & NS & NS & 0.001 & 0.01 & NS & 0.05 & 0.05 \\
\hline
\end{tabular}

* See footnote to Table I.

The effect of INDO on basal and experimental $\mathrm{Na}$ and $\mathrm{Cl}$ fluxes in control and agonist-treated colons are shown in Tables I (section B) and II (section B). INDO had no effect on basal net $\mathrm{Na}$ and $\mathrm{Cl}$ fluxes by the control rat colon. However, INDO significantly decreased the basal Isc. This suggests that INDO affected the basal rate of transport of other ions $(K$, $\mathrm{HCO}_{3}, \mathrm{Ca}$, etc.), although this was not confirmed with corresponding changes in $J_{\text {Net }}{ }^{R}$. The lack of effect of INDO on anti-IgE-induced inhibition of neutral $\mathrm{NaCl}$ absorption is also shown in Table I (section B). The inhibition of the neutral $\mathrm{NaCl}$ absorption noted with ROS, however, was reduced by INDO pretreatment (Table II [section B]), as was the electrogenic secretion of $\mathrm{Cl}$. The blockade of prostaglandin synthesis with INDO thus inhibited the electrogenic $\mathrm{Cl}$ secretion stimulated by these immune system agonists and had a variable ability to prevent the inhibition of neutral $\mathrm{NaCl}$ absorption.

Because degranulating mast cells also release histamine, we studied the effect of the $\mathrm{H}_{1}$-receptor antagonist diphenhydramine (DPH) on the $\Delta I$ sc to anti-IgE. As shown in Fig. 7, DPH inhibited the $\Delta I$ sc by $\sim 50 \%$ as compared with $70 \%$ inhibition with INDO. The inhibition with a combination of DPH and INDO was not statistically different from that with INDO alone. These studies suggest that both histamine and eicosanoids were being released by anti-IgE stimulation and that histamine can trigger an increased $\Delta I$ sc either directly or through the release of eicosanoids. Furthermore, because phagocytes also have low-affinity IgE receptors (23), but don't produce histamine, this indicates that mast cells were being degranulated in rat colon.

Eicosanoid production stimulated by immune system agonists. The lack of an additive effect of INDO and NDGA on the $\Delta I \mathrm{sc}_{\text {MAX }}$ (Table IV) suggests that NDGA, which is not specific for the lipoxygenase pathway of AA metabolism, may have also interfered with the formation of a cyclooxygenase product. To investigate this possibility, $\mathrm{PGE}_{2}$ production was measured in control and agonist-stimulated tissues with or without prior pretreatment with either INDO or NDGA. Prostaglandin production peaked in the first or, more commonly, in the second 15-min period after addition of the immune system agonists and then declined toward, but not to, basal

Table III. Effect by (A) ROS Created by the X $(0.7 \mathrm{mM}) / X O(20.8 \mathrm{mU} / \mathrm{ml})$ Reaction on Rat Colonic Electrolyte Transport and $(B)$ Response to TTX $\left(10^{-7} M\right),(n=5)^{*}$

\begin{tabular}{|c|c|c|c|c|c|c|c|c|c|c|}
\hline & $J_{\operatorname{ma}}^{\mathrm{Na}}$ & $J_{\mathrm{m} m}^{\mathrm{Non}}$ & $J_{\mathrm{net}}^{\mathrm{Na}}$ & $J_{m a}^{a}$ & $J_{\mathrm{m}}^{\mathrm{a}}$ & $J_{\text {net }}^{\mathrm{a}}$ & Isc & $J_{\mathrm{net}}^{R}$ & PD & G \\
\hline & \multicolumn{8}{|c|}{$\mu e q / h_{\text {per }} \mathrm{cm}^{2}$} & $m V$ & $\mathrm{mS} / \mathrm{cm}^{2}$ \\
\hline \multicolumn{11}{|l|}{$A$} \\
\hline (i) Basal & $15.0 \pm 1.4$ & $10.1 \pm 0.9$ & $4.8 \pm 0.8$ & $18.8 \pm 1.9$ & $15.1 \pm 0.8$ & $3.7 \pm 1.2$ & $1.5 \pm 0.3$ & $0.3 \pm 0.3$ & $-1.7 \pm 0.3$ & $22.3 \pm 2.9$ \\
\hline (ii) $\mathrm{X} / \mathrm{XO}$ & $12.0 \pm 1.4$ & $10.9 \pm 1.2$ & $1.1 \pm 0.8$ & $15.1 \pm 1.3$ & $17.3 \pm 0.7$ & $-2.3 \pm 0.8$ & $3.1 \pm 0.2$ & $-0.3 \pm 0.9$ & $-3.9 \pm 0.5$ & $22.4 \pm 2.4$ \\
\hline (ii vs. $i)$ & $P<0.01$ & NS & 0.01 & 0.01 & 0.001 & 0.01 & 0.001 & NS & 0.01 & NS \\
\hline \multicolumn{11}{|l|}{$B$} \\
\hline (iii) TTX & $16.7 \pm 1.1$ & $10.5 \pm 1.5$ & $6.2 \pm 0.8$ & $21.6 \pm 1.5$ & $14.9 \pm 2.0$ & $6.7 \pm 0.7$ & $0.8 \pm 0.2$ & $1.3 \pm 0.2$ & $-0.9 \pm 0.2$ & $23.4 \pm 2.9$ \\
\hline (iv) $\mathrm{TTX}+\mathrm{X} / \mathrm{XO}$ & $15.5 \pm 1.5$ & $11.1 \pm 1.7$ & $4.5 \pm 0.9$ & $18.7 \pm 1.6$ & $15.3 \pm 2.3$ & $3.4 \pm 0.9$ & $1.4 \pm 0.3$ & $0.4 \pm 0.3$ & $-1.7 \pm 0.3$ & $24.5 \pm 4.1$ \\
\hline (iv vs. $i i i)$ & $P<0.05$ & NS & 0.01 & 0.001 & NS & 0.001 & 0.01 & NS & 0.05 & NS \\
\hline (iv vs. $i)$ & $P<\mathrm{NS}$ & NS & NS & NS & NS & NS & NS & NS & 0.05 & NS \\
\hline (iv vs. $i i)$ & $P<\mathrm{NS}$ & NS & 0.05 & NS & NS & 0.01 & 0.01 & NS & 0.05 & NS \\
\hline
\end{tabular}

* See footnote to Table I. 
Table IV. Effect of Cyclooxygenase and Lipoxygenase Inhibitors on Colonic Short-Circuit Current Response ( $\left.\Delta I \mathrm{Ic}_{\mathrm{MAX}}\right)$ to Immune System Agonists

\begin{tabular}{|c|c|c|c|c|}
\hline \multirow[b]{2}{*}{ Agonist } & \multirow[b]{2}{*}{$\Delta \mathrm{Isc}_{\max }{ }^{*}$ control $(n)$} & \multicolumn{3}{|c|}{ Percent of control response } \\
\hline & & $\operatorname{INDO}\left(10^{-6} \mathrm{M}\right)$ & $\operatorname{NDGA}\left(10^{-6} \mathrm{M}\right)$ & NDGA + INDO $\left(10^{-6} \mathrm{M}\right.$ each $)$ \\
\hline & $\mu A / \mathrm{cm}^{2}$ & \multicolumn{3}{|c|}{$\%$} \\
\hline Anti-IgE $(3 \mu g / m l)$ & $63.7 \pm 8.6(7)$ & $36.0 \pm 7.7^{\ddagger}$ & $70.9 \pm 8.4^{\ddagger}$ & $42.3 \pm 9.7^{\ddagger}$ \\
\hline $\operatorname{FMLP}\left(10^{-4} M\right)$ & $20.0 \pm 6.6(5)$ & $11.6 \pm 10.6^{\ddagger}$ & $44.6 \pm 33.2$ & $0.0 \pm 9.1^{\ddagger}$ \\
\hline $\operatorname{PAF}\left(10^{-5} M\right)$ & $57.0 \pm 8.7(7)$ & $11.1 \pm 4.1^{\ddagger}$ & $38.1 \pm 9.7^{\ddagger}$ & $17.7 \pm 8.8^{\ddagger}$ \\
\hline $\mathrm{X}(0.7 \mathrm{mM}) / \mathrm{XO}(20.8 \mathrm{mU} / \mathrm{ml})$ & $59.7 \pm 5.7(6)$ & $27.8 \pm 10.7^{\ddagger}$ & $56.7 \pm 11.6^{\ddagger}$ & $23.2 \pm 15.1^{\ddagger}$ \\
\hline
\end{tabular}

$* \Delta I s c_{\mathrm{MAX}}=$ Peak change in Isc at 3-6 min after addition of agonists to the serosal bathing solution. ${ }^{\ddagger} P<0.02$ agonist versus agonist plus inhibitors.

levels at 30-45 min after addition of the agonist. Except for FMLP, which is a poor Isc stimulant in rat colon, the other three agonists all significantly increased $\mathrm{PGE}_{2}$ production two to threefold (Fig. 8). Pretreatment with INDO not only prevented this increase in $\mathrm{PGE}_{2}$, but also reduced $\mathrm{PGE}_{2}$ production below basal levels as well. NDGA was moderately effective as a cyclooxygenase inhibitor. It did not suppress PGE $_{2}$ production below basal levels, but NDGA did inhibit the stimulation of $\mathrm{PGE}_{2}$ production by these agonists. This lends support to the idea that the inhibition of the Isc response by NDGA was the result of partial inhibition of prostaglandin synthesis by this nonspecific eicosanoid pathway inhibitor.

Enteric nervous system-prostaglandin interactions. Because it has recently been suggested that prostaglandins, particularly $\mathbf{P G I}_{2}$, might activate enteric nerves (24-29), we correlated the effects of enteric nervous system and cyclooxygenase inhibitors on immune system agonist-stimulated colonic $\Delta I \mathrm{sc}_{\mathrm{MAX}}$ and prostaglandin production. Table $\mathrm{V}$ compares the

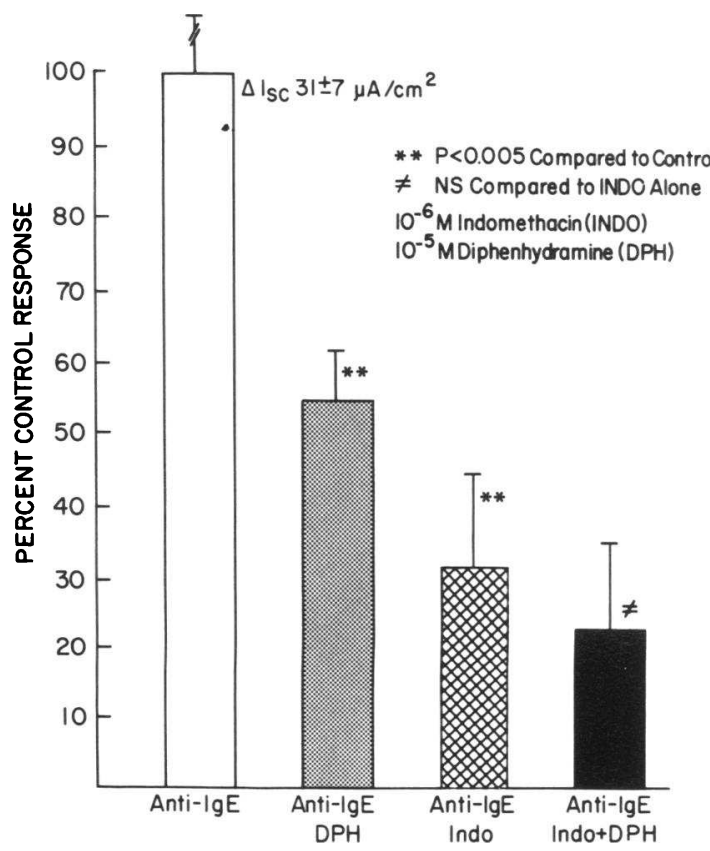

Figure 7. Isc response of rat colon to sheep anti-rat IgE $(3 \mu \mathrm{g} / \mathrm{ml}, n$ $=6)$ is significantly inhibited by DPH $\left(10^{-5} \mathrm{M}\right)$ and by INDO $\left(10^{-6}\right.$ $M)$. The inhibition of $\Delta I s c$ by the combination of the INDO and

DPH was not statistically different from that shown with INDO alone. control Isc response with the various agonists with the response after preincubation with neural inhibitors such as TTX, HEX, and ATR. In the same tissues, we determined the response to the cyclooxygenase blockers INDO and PXM. The neural inhibitors and cyclooxygenase blockers reduced the $\Delta I$ sc to $60-90 \%$ of control levels. ATR at $10^{-6} \mathrm{M}$ decreased the $\Delta$ Isc $_{\text {MAX }}$ by only $10-20 \%$; it required a large concentration of $50 \mu \mathrm{M}$ to accomplish a significant degree of inhibition. The neural inhibitors and cyclooxygenase blockers reduced the $\Delta I \mathbf{s c}_{\text {MAX }}$ of both peaks of the biphasic response to PAF and $\mathrm{X} / \mathrm{XO}$.

The effects of TTX on X/XO-induced alterations in colonic electrolyte transport are shown in Table III (section B). TTX had no statistically significant effect on basal $\mathrm{Na}$ and $\mathrm{Cl}$ absorption in the control tissues. TTX did effectively prevent the reduction in neutral $\mathrm{NaCl}$ absorption $\left(J_{\mathrm{Net}}^{\mathrm{Na}}\right.$ and $\left.J_{\mathrm{Net}}^{\mathrm{C}}\right)$ and prevented the stimulation of electrogenic $\mathrm{Cl}$ secretion $(\Delta I \mathrm{sc})$ brought about by $\mathrm{X} / \mathrm{XO}$. These data and those given in Table $\mathrm{V}$ indicate that a significant portion of the immune system agonist effect is mediated by the enteric nervous system.

It is conceivable that the enteric nervous system could be releasing prostaglandins that in turn might directly stimulate the enterocyte. Alternatively, prostaglandins released from immune and mesenchymal cells could be releasing neurotransmitters from the enteric nervous system that then stimulate the enterocyte. To determine which of these sequences was more likely, we measured prostaglandin production in the

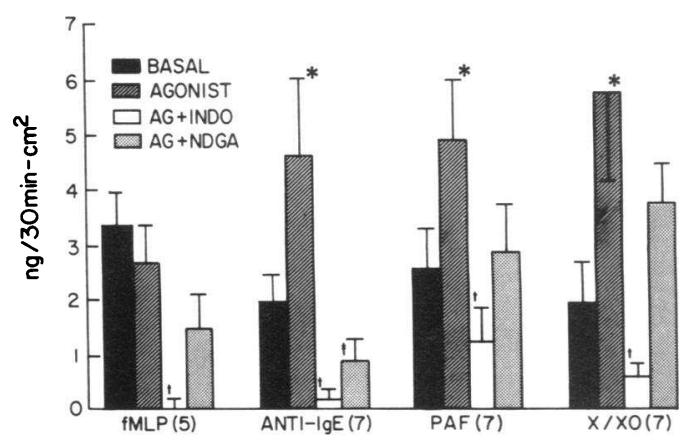

Figure 8. Effect of INDO $\left(10^{-6} \mathrm{M}\right)$ and NDGA $\left(10^{-6} \mathrm{M}\right)$ on $\mathrm{PGE}_{2}$ secretion into the serosal bathing solution of Ussing chambered-rat colon in response to the various immune system agonists. ${ }^{*} P<0.01$ comparing basal with agonist; $\nmid P<0.01$ comparing agonist to INDO plus agonist; $\ddagger P<0.01$ comparing agonist to NDGA plus agonist. 
Table V. Effect of Cyclooxygenase and Neural Inhibitors on Colonic Short-Circuit Current Response ( $\left.\Delta I s c_{M A X}\right)$ to Immune System Agonists

\begin{tabular}{|c|c|c|c|c|c|c|}
\hline \multirow[b]{2}{*}{ Agonist } & \multirow[b]{2}{*}{$\Delta / \mathrm{sc}_{\mathrm{MAX}}$ control $(n)^{*}$} & \multicolumn{5}{|c|}{ Percent of control response } \\
\hline & & $\operatorname{INDO}\left(10^{-6} \mathrm{M}\right)$ & $\operatorname{PXM}\left(10^{-6} \mathrm{M}\right)$ & $\operatorname{TTX}\left(10^{-7} \mathrm{M}\right)$ & $\operatorname{HEX}\left(10^{-5} \mathrm{M}\right)$ & $\operatorname{ATR}\left(5 \times 10^{-5} \mathrm{M}\right)$ \\
\hline & $\mu A / \mathrm{cm}^{2}$ & & & $\%$ & & \\
\hline Anti-rat IgE $(3 \mu g / m l)$ & $51.8 \pm 5.5(8)$ & $28.8 \pm 8.5^{\ddagger}$ & $20.6 \pm 4.8^{\ddagger}$ & $22.6 \pm 8.2^{\ddagger}$ & $64.1 \pm 6.0^{\ddagger}$ & $28.5 \pm 8.2^{\ddagger}$ \\
\hline \multicolumn{7}{|l|}{ FMLP } \\
\hline $\operatorname{Rat}\left(10^{-4} M\right)$ & $28.8 \pm 3.9(5)$ & $4.5 \pm 2.0^{\ddagger}$ & $15.4 \pm 3.2^{\ddagger}$ & $33.3 \pm 10.4^{\ddagger}$ & $41.3 \pm 11.5^{\ddagger}$ & $24.6 \pm 10.2^{\ddagger}$ \\
\hline Rabbit $\left(10^{-8} M\right)$ & $49.7 \pm 5.4(6)$ & $0.6 \pm 1.9^{8}$ & - & $58.3 \pm 15.9^{\S}$ & - & $45.8 \pm 12.2^{8}$ \\
\hline \multicolumn{7}{|l|}{$\operatorname{PAF}\left(10^{-5} M\right)$} \\
\hline Peak 1 & $65.6 \pm 7.4(5)$ & $10.0 \pm 3.4^{\ddagger}$ & $14.0 \pm 5.4^{\ddagger}$ & $26.7 \pm 12.4^{\ddagger}$ & $56.5 \pm 12.8^{\ddagger}$ & $34.6 \pm 10.4^{\ddagger}$ \\
\hline Peak 2 & $65.6 \pm 10.2(5)$ & $19.6 \pm 10.3^{\ddagger}$ & $24.1 \pm 14.4^{\ddagger}$ & $9.8 \pm 3.3^{\ddagger}$ & $42.5 \pm 23.1^{\ddagger}$ & $19.9 \pm 13.1^{\ddagger}$ \\
\hline \multicolumn{7}{|c|}{$\mathrm{X}(0.7 \mathrm{mM}) / \mathrm{XO}(20.8 \mathrm{mU} / \mathrm{ml})$} \\
\hline Peak 1 & $68.4 \pm 8.7(5)$ & $26.0 \pm 7.6^{\ddagger}$ & $17.1 \pm 8.6^{\ddagger}$ & $13.5 \pm 2.7^{\ddagger}$ & $42.5 \pm 14.6^{\ddagger}$ & $28.0 \pm 6.7^{\ddagger}$ \\
\hline Peak 2 & $74.4 \pm 20.8(5)$ & $11.3 \pm 10.7^{\ddagger}$ & $3.4 \pm 5.9^{\ddagger}$ & $33.7 \pm 17.6^{\ddagger}$ & $65.0 \pm 29.8$ & $39.7 \pm 12.6$ \\
\hline
\end{tabular}

* $\Delta I \mathrm{sc}_{\mathrm{MAX}}=$ peak change in Isc from baseline at either 3-6 min after addition of agonists to the serosal bathing solution (peak 1) or at 15 min (PAF) or $30 \mathrm{~min}(\mathrm{X} / \mathrm{XO})$ after the addition of agonist (peak 2). ${ }^{\ddagger} P<0.005$ agonist versus agonist plus inhibitors. ${ }^{8} P<0.02$ agonist versus agonist plus inhibitors.

presence of both neural inhibitors and cyclooxygenase blockers (Tables VI and VII). Basal $\mathrm{PGE}_{2}$ and $\mathrm{PGI}_{2}$ production (as measured by assaying for the 6 keto-PGF ${ }_{1 \alpha}$ metabolite) were variable from study to study, but $\mathrm{PGE}_{2}$ production was

Table VI. PGE $E_{2}$ and Prostacyclin (measured as 6 keto-PGF $F_{1 \alpha}$ ) Production by Rat and Rabbit Colon in Response to Immune Cell Stimulants and Neural or Cyclooxygenase Inhibitors

\begin{tabular}{|c|c|c|}
\hline $\begin{array}{l}\text { Agonist (concentration) }(n) \\
+ \text { inhibitors (concentration) }\end{array}$ & $\mathrm{PGE}_{2}$ & 6 keto-PGF $F_{\text {la }}$ \\
\hline & \multicolumn{2}{|c|}{$\mathrm{ng} / 30$ min per $\mathrm{cm}^{2}$} \\
\hline \multicolumn{3}{|l|}{ Anti-rat IgE $(3 \mu g / m l)(n=8)$} \\
\hline Control & $1.4 \pm 0.2$ & $2.4 \pm 0.4$ \\
\hline Agonist alone & $2.2 \pm 0.2$ & $3.7 \pm 0.7$ \\
\hline$(+) \operatorname{TTX}\left(10^{-7} M\right)$ & $2.0 \pm 0.3$ & $2.5 \pm 0.5$ \\
\hline$(+) H E X\left(10^{-5} M\right)$ & $1.7 \pm 0.6$ & $2.8 \pm 0.6$ \\
\hline$(+) \operatorname{ATR}\left(5 \times 10^{-5} M\right)$ & $1.8 \pm 0.4$ & $3.4 \pm 0.7$ \\
\hline$(+) \operatorname{INDO}\left(10^{-6} M\right)$ & $0.1 \pm 0.1^{* \pm}$ & $-0.1 \pm 0.7^{* \neq}$ \\
\hline$(+) \mathrm{PXM}\left(10^{-6} M\right)$ & $0.7 \pm 0.4^{\ddagger}$ & $0.8 \pm 0.04^{\ddagger}$ \\
\hline \multicolumn{3}{|l|}{ FMLP } \\
\hline \multicolumn{3}{|l|}{$\operatorname{Rat}\left(10^{-4} M\right)(n=3)$} \\
\hline Control & $0.9 \pm 0.1$ & $2.2 \pm 0.8$ \\
\hline Agonist alone & $0.4 \pm 0.4$ & $-4.1 \pm 2.4$ \\
\hline$(+) \operatorname{TTX}\left(10^{-7} M\right)$ & $1.1 \pm 1.2$ & $-6.1 \pm 4.7$ \\
\hline$(+) \operatorname{HEX}\left(10^{-5} M\right)$ & $1.6 \pm 0.2$ & $-1.7 \pm 1.7$ \\
\hline$(+) \operatorname{ATR}\left(5 \times 10^{-5} M\right)$ & $1.2 \pm 0.5$ & $-2.8 \pm 2.9$ \\
\hline$(+) \operatorname{INDO}\left(10^{-6} M\right)$ & $0.2 \pm 0.2$ & $-8.7 \pm 9.0$ \\
\hline$(+) \operatorname{PXM}\left(10^{-6} M\right)$ & $0.0 \pm 0.1$ & $-3.8 \pm 2.0$ \\
\hline \multicolumn{3}{|l|}{ Rabbit $\left(10^{-8} M\right)(n=6)$} \\
\hline Control & $1.1 \pm 2.8$ & $0.1 \pm 0.8$ \\
\hline Agonist alone & $10.6 \pm 2.6^{*}$ & $3.7 \pm 1.0^{*}$ \\
\hline$(+) \operatorname{TTX}\left(10^{-7} M\right)$ & $7.2 \pm 3.4^{*}$ & $3.1 \pm 1.3^{*}$ \\
\hline$(+) \operatorname{INDO}\left(10^{-6} M\right)$ & $-2.6 \pm 3.2^{\ddagger}$ & $0.2 \pm 0.6^{\ddagger}$ \\
\hline
\end{tabular}

\footnotetext{
* $P<0.01$ control versus agonist or agonist plus inhibitor.

${ }^{\ddagger} P<0.01$ agonist versus agonist plus inhibitor.
}

significantly less than 6 keto-PGF ${ }_{1 \alpha}$ in the rat. Both prostaglandins were increased significantly by anti-IgE, PAF, and $\mathrm{X} / \mathrm{XO}$. Although no increases in PG could be demonstrated in the rat colon after exposure to FMLP, this peptide increased rabbit colonic $\mathrm{PGE}_{2}$ production 10-fold. In the rat colon, the immune cell products PAF and ROS were better stimulants of PG production (5-17-fold) than the immune cell stimuli antiIgE and FMLP (0-1.5-fold). PAF and ROS stimulated more 6 keto-PGF ${ }_{1 \alpha}$ production $\left(\sim 15\right.$-fold) than PGE $_{2}$ production

Table VII. PGE $E_{2}$ and Prostacyclin (measured as 6 keto-PGF $F_{1 a}$ ) Production by Rat Colon in Response to Immune Cell Products and Neural or Cyclooxygenase Inhibitors

\begin{tabular}{|c|c|c|}
\hline $\begin{array}{l}\text { Agonist (concentration) }(n) \\
\text { plus inhibitors (concentration) }\end{array}$ & $\mathrm{PGE}_{2}$ & 6 keto-PGF $1 \alpha$ \\
\hline & \multicolumn{2}{|c|}{$\left(\mathrm{ng} / 30 \min\right.$ per $\left.\mathrm{cm}^{2}\right)$} \\
\hline \multicolumn{3}{|l|}{$\operatorname{PAF}\left(10^{-5} M\right)(n=5)$} \\
\hline Control & $0.5 \pm 0.2$ & $1.9 \pm 0.6$ \\
\hline Agonist alone & $2.6 \pm 0.5^{*}$ & $26.7 \pm 6.4^{*}$ \\
\hline$(+) \operatorname{TTX}\left(10^{-7} M\right)$ & $2.0 \pm 0.6$ & $30.2 \pm 7.7^{*}$ \\
\hline$(+) \operatorname{HEX}\left(10^{-5} M\right)$ & $2.7 \pm 0.6^{*}$ & $41.2 \pm 12.0^{*}$ \\
\hline$(+) \operatorname{ATR}\left(5 \times 10^{-5} M\right)$ & $3.5 \pm 1.3^{*}$ & $36.2 \pm 9.0^{*}$ \\
\hline$(+) \operatorname{INDO}\left(10^{-6} M\right)$ & $-0.4 \pm 0.2^{\ddagger}$ & $2.1 \pm 1.0^{\ddagger}$ \\
\hline$(+) \operatorname{PXM}\left(10^{-6} M\right)$ & $-0.2 \pm 0.1^{\ddagger}$ & $0.4 \pm 1.0^{\ddagger}$ \\
\hline \multicolumn{3}{|c|}{$\mathrm{X}(0.7 \mathrm{mM}) / \mathrm{XO}(20.8 \mathrm{mU} / \mathrm{ml})(n=5)$} \\
\hline Control & $1.3 \pm 0.5$ & $1.5 \pm 0.2$ \\
\hline Agonist alone & $5.9 \pm 0.2^{*}$ & $26.6 \pm 3.6^{*}$ \\
\hline$(+) \operatorname{TTX}\left(10^{-7} M\right)$ & $6.6 \pm 0.6^{*}$ & $22.0 \pm 3.6^{*}$ \\
\hline$(+) H E X\left(10^{-5} M\right)$ & $6.1 \pm 0.1^{*}$ & $23.8 \pm 4.8^{*}$ \\
\hline$(+) \operatorname{ATR}\left(5 \times 10^{-5} M\right)$ & $6.3 \pm 0.5^{*}$ & $19.4 \pm 4.5^{*}$ \\
\hline$(+) \operatorname{INDO}\left(10^{-6} M\right)$ & $1.5 \pm 0.3^{\ddagger}$ & $4.9 \pm 1.4^{\ddagger}$ \\
\hline$(+) \mathrm{PXM}\left(10^{-6} M\right)$ & $1.8 \pm 0.6^{\ddagger}$ & $5.1 \pm 1.8^{\ddagger}$ \\
\hline
\end{tabular}

\footnotetext{
* $P<0.005$ control versus agonist or agonist plus inhibitor.

${ }^{\ddagger} P<0.005$ agonist versus agonist plus inhibitor.
} 
(increased fivefold). Of importance is the lack of inhibition of PG production by the neural inhibitors while in the same tissues significant inhibition was demonstrated with INDO and PXM. When viewed in conjunction with the simultaneously measured $\Delta I \mathrm{sc}_{\mathrm{MAX}}$ (Table $\mathrm{V}$ ), these data suggest that the alteration in electrolyte transport was the result of the enteric nervous system being stimulated by cyclooxygenase products rather than prostaglandins being released in response to neural stimulation.

\section{Discussion}

Three main classes or groups of agents have been identified that alter intestinal electrolyte transport: neurotransmitters, hormones, and bacterial enterotoxins (30). The enteric nervous system stimulates intestinal secretion through neurotransmitters such as acetylcholine ( $\mathrm{ACh}$ ) and vasoactive intestinal polypeptide (VIP) and stimulates intestinal absorption with neurotransmitters such as $\alpha_{2}$-adrenergic agents, enkephalins and somatostatin. An example of endocrine or hormonal control is aldosterone-enhancement of $\mathrm{Na}$ and water absorption from the colon. The third group is represented by enterocyte receptors for bacterial enterotoxins, such as those elaborated by Esherichia coli and Vibrio cholerae, which are important causes of pathologic alterations of water and electrolyte transport. We believe the data presented here are confirmatory evidence for an additional regulatory system: the immune system (31). We have shown that stimuli of immune cells, as well as products of immune cell stimulation, are capable of altering intestinal electrolyte transport. Furthermore, the evidence suggests that cyclooxygenase products of AA metabolism and the enteric nervous system play a central role in mediating this effect.

Mast cells and phagocytes are two types of immune effector cells that release soluble mediators in the lamina propria in response to stimuli such as anti-IgE and FMLP, which are reasonably specific for these two classes of effector cells. These stimuli activate immune effector cells through receptor-mediated phosphoinositol metabolism $(32,33)$. Mucosal mast cells, which play an important role in hypersensitivity responses such as those demonstrated after sensitization to egg or milk protein or to nematodes (34), are degranulated when receptor bound IgE molecules are cross-linked by antigen. In a laboratory setting, a convenient antigen for cross-linking IgE receptors is antibody raised in one animal species against the IgE of the experimental species. Here, we have used sheep anti-rat IgE. Since phagocytic cells have low-affinity IgE receptors, the response to anti-IgE may not be specific for the mast cell. However, our $\mathrm{Cl}$-secretory response was partially inhibited by a $\mathrm{H}_{1}$ antagonist, indicating that histamine was being released from mast cells after anti-IgE application to rat colon. Phagocytes, which include eosinophils, neutrophils, and macrophages, play important roles in infectious or idiopathic inflammation. To stimulate phagocytic cells, we have used the chemotactic peptide FMLP. This formylated tripeptide seems to be specific for phagocytes; mast celis do not respond to FMLP (18). Both anti-IgE and FMLP proved cap'able of altering intestinal electrolyte transport.

Once activated, mast cells and phagocytes release many products capable of stimulating other immune or mesenchymal cells or the enterocyte. For example, phagocytes and mast cells release prostaglandins, leukotrienes, PAF, ROS, and cytokines $(34,35)$. Mast cell also release histamine, serotonin, and adenosine, all of which are secretogogues in the intestine (30). We have investigated two of the less well-studied mediators produced by mast cells and phagocytes; PAF and ROS. Both appear to be potent stimuli of intestinal $\mathrm{Cl}$ secretion. PAF is a phosphatidylcholine species with an $O$-alkyl ether residue at the $s n-1$ position and an acyl-acetyl group at the $s n-2$ position of the glycerol. It is a potent activator of phagocytes, but also is believed to stimulate other cells, including those in the gastrointestinal tract (17). We have created ROS by the $\mathrm{X} / \mathrm{XO}$ reaction which initially forms superoxide anion $\left(\mathrm{O}_{\overline{2}}^{\overline{2}}\right)$, a species that is rapidly changed to hydrogen peroxide $\left(\mathrm{H}_{2} \mathrm{O}_{2}\right)$ through both spontaneous and enzymatic dismuiation (36). Preliminary evidence suggests that it is $\mathrm{H}_{2} \mathrm{O}_{2}$ rather than $\mathrm{O}_{\overline{2}}^{-}$or the hydroxyl radical that is responsible for the $\mathrm{Cl}$ secretion in rat colon (22).

Although it is possible that these immune cell stimulants and products might directly affect the epithelium, we present evidence here that prostaglandins play a central role in the changes in electrolyte transport brought about by these agonists. The responses to these agonists were inhibited by $50-75 \%$ by two classes of cyclooxygenase blockers, INDO and PXM. Furthermore, we were able to demonstrate significant increases in $\mathrm{PGE}_{2}$ and 6 keto $\mathrm{PGF}_{1 \alpha}$, the latter being the major degradation product of $\mathrm{PGI}_{2}$. The PG responses to FMLP (rabbit) and anti-IgE (rat) were not as profound as that with the immune cell products PAF and ROS. We could not demonstrate FMLP-stimulated synthesis of either in the rat. However, as noted above, the rat is a poor responder to chemotactic peptide. The interpretation of the role of the prostaglandins in the FMLP-mediated response is further complicated by the fact that both INDO and PXM may block the FMLP receptor (37-39). Therefore, the decrease in response demonstrated after preincubation with these cyclooxygenase inhibitors could come about through blockade of FMLP receptors rather than blockade of prostaglandin synthesis. However, it requires considerably higher drug concentrations to block FMLP receptors ( $50 \%$ blockade at $50 \mu \mathrm{M}$ ) than to block prostaglandin synthesis $(\sim 100 \%$ at $1 \mu \mathrm{M})$, so it seems likely that a considerable part of the inhibition of the $\Delta I s c$ seen with PXM and INDO was due to decreased prostaglandin synthesis.

The stimulation of $\mathrm{PGI}_{2}$ production by anti-IgE was not as great as that seen by PAF and ROS (contrast Tables VI with VII). Mast cell degranulation might result in $\mathrm{Cl}$ secretion through release of some of its other mediators such as histamine, serotonin or adenosine. Indeed, $\mathrm{H}_{1}$-receptor blockade effectively reduced the $\Delta I s c$ to anti-IgE in the rat (Fig. 7). However, the ability of INDO and PXM to significantly inhibit the $\Delta I s c$ to anti-IgE suggest that prostaglandins are more important intermediates. Furthermore, there is evidence that histamine releases prostaglandins in the rat colon (40), an event that would explain the lack of an additive effect between $\mathrm{H}_{1}$-antagonists and cyclooxygenase blockade. $\mathrm{PGD}_{2}$ is reported as the major prostaglandin synthesized by the mast cell (3), whereas thromboxane $A_{2}$ is the major prostaglandin produced by phagocytes (41). It is conceivable that these might also be important prostaglandins mediating the $\mathrm{Cl}$ secretion of anti-IgE and FMLP stimulation in the rat.

The two immune cell products PAF and ROS stimulated significant increases in both $\mathrm{PGE}_{2}(\sim 5$-fold) and in 6 keto $\mathrm{PGF}_{1 \alpha}(\sim 15$-fold $)$. The ability of PAF to stimulate eicosanoid 
production by immune and mesenchymal cells is well known (17). However, the eicosanoid response to ROMs is less well recognized.

Our studies do not implicate any significant role for lipoxygenase products in the stimulation of $\mathrm{Cl}$ secretion by the immune system. There was minimal inhibition of the $\Delta I s c$ by NDGA and that response was not additive to that observed with INDO alone. Furthermore, we found that NDGA inhibited agonist-induced increases in $\mathrm{PGE}_{2}$, in keeping with its known lack of specificity for the lipoxygenase pathway. These studies, however, do not rule out a role for lipoxygenase products in immune system-mediated alterations in electrolyte transport. Lipoxygenase products do alter intestinal electrolyte transport in the Ussing Chamber $(6,42)$. However, a good part of that effect is inhibited by INDO suggesting that lipoxygenase products act primarily on immune or mesenchymal cells stimulating release prostaglandins, which then cause $\mathrm{Cl}$ secretion. We have documented two responses to the immune system agonists: electrogenic $\mathrm{Cl}$ secretion $(\Delta I s c)$ and inhibition of neutral $\mathrm{NaCl}$ absorption. INDO did not completely abolish the inhibition of neutral $\mathrm{NaCl}$ absorption brought about by anti-IgE (see Table I [section B]), but it reduced the $\Delta I$ sc by $>70 \%$. Perhaps prostaglandins are responsible for the electrogenic $\mathrm{Cl}$ secretion from the colonic crypts, whereas lipoxygenase products might be responsible for the inhibition of neutral $\mathrm{NaCl}$ absorption from the colonic surface epithelium. This has been suggested by others (42), but remains to be demonstrated by more rigorous studies. It is also equally possible that serotonin, adenosine or some other secretagogue released from mast cells might also be responsible for the inhibition of neutral $\mathrm{NaCl}$ absorption.

The alterations in transport reported here could come about through receptor-mediated stimulation of enterocyte adenylate cyclase (43). However, there is emerging evidence that the effects of prostaglandins on intestinal electrolyte transport are not all mediated through activation of enterocyte adenylate cyclase. Rask-Madsen and colleagues have shown that prostaglandins can stimulate intestinal secretion at concentrations far below those necessary to stimulate adenylate cyclase in the intestine $(44,45)$. Furthermore, this stimulatory process is sensitive to the level of ambient $\mathrm{Ca}^{2+}$ and is inhibited by calcium channel blockers. Several studies have demonstrated that prostaglandins will release neurotransmitters, particularly $\mathrm{ACh}$, from the enteric nervous system (24-29, 44, 45). Furthermore, the $\Delta I$ sc response of rat colon to exogenous prostaglandins, particularly $\mathbf{P G I}_{2}$, is inhibited by removal of the enteric nervous system or TTX blockade $(28,29)$, a finding we have confirmed (unpublished observations).

We have shown here that TTX, HEX, and ATR can inhibit the responses to immune cell stimuli and products. Furthermore, the release of prostaglandins by various immune agonists was not inhibited by neural blockade, indicating that it is the PGs which stimulate the enteric nervous system and not vice versa. The $50-90 \%$ inhibition of $\Delta I$ sc after preincubation with TTX, HEX, and ATR implies that prostaglandinmediated release of neurotransmitters from the enteric nervous system is a major, ultimate stimulant of electrogenic $\mathrm{Cl}$ secretion in rat.colon. The inhibition of the $\Delta / \mathrm{sc}$ response with ATR suggests that $\mathrm{ACh}$ is an important neurotransmitter. However, because it required high concentrations of ATR (50 $\mu \mathrm{M})$ to significantly inhibit these responses, it is possible that the atropine effect was the result of nicotinic blockade of the enteric nervous system rather than muscarinic blockade of $\mathrm{ACh}$ receptors on the colonocyte.

Two different responses were observed: a brief Isc response to immune cell stimulants and a prolonged, biphasic response to immune cell products. The brief response to anti-IgE or FMLP resembles that elicited in the colon by $\mathrm{ACh}$ or $\mathrm{ACh}$ analogues $(46,47)$. However, it could represent a response to some other released agonist (e.g., serotonin) or, conceivably, the brief response could signify tachyphylaxis to the released prostaglandin (48). The biphasic and sustained response to PAF and ROS would be the result of release of long-acting neurotransmitters such as vasoactive intestinal polypeptide, or due to a direct effect of the released prostaglandins or of PAF and ROS themselves on the epithelium. In that regard, we have been able to demonstrate a stimulation of Isc in the T84 colon carcinoma cell line with PAF and $\mathrm{H}_{2} \mathrm{O}_{2}$, but not with FMLP or anti-IgE (Berschneider, H., unpublished observations). Thus, the varied responses could be due to neurotransmitter-epithelial cell interactions of varying proportions and timing. Furthermore, the responses might be different in the small and large intestine and in various animal species.

The electrolyte transport responses reported here have been noted to some degree with other immune cell stimulants such as leukotrienes $(6)$, phorbol esters $(49,50)$ and interleukins (51). The responses to these agonists are all partially inhibited by cyclooxygenase blockers. Furthermore, models of intestinal anaphylaxis created by sensitization to various proteins respond to specific antigen and inhibitors in the Ussing chamber in a manner similar to that reported here (52-56).

Fig. 9 represents a current working model for immune system control of intestinal electrolyte transport. This model is in keeping with the growing body of knowledge suggesting close interactions between the immune system and the neuro-

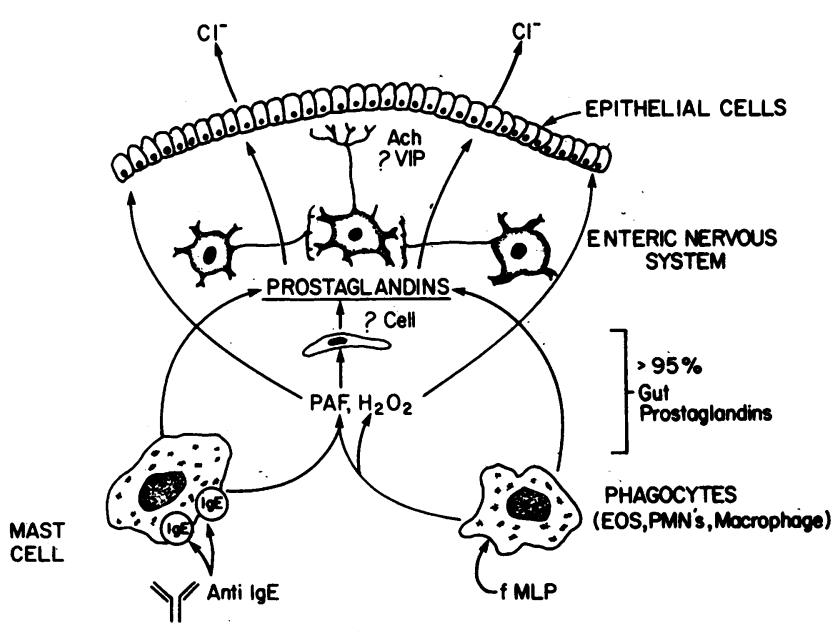

Figure 9. Proposed model for immune system-mediated alterations in colonic electrolyte transport. In this model, stimulants of mast cells (anti-IgE) or of phagocytes (FMLP) and immune cell products (PAF or $\mathrm{H}_{2} \mathrm{O}_{2}$ ) release prostaglandins from immune cells and mesenchymal cells in the lamina propria of the intestine. The prostaglandins (or other novel cyclooxygenase metabolites) may directly stimulate the epithelial cells to secrete $\mathrm{Cl}$. However, at least $50 \%$ of rat colonic $\mathrm{Cl}$ secretion appears to be mediated by activation of the enteric nervous system by these cyclooxygenase products. The final neurotransmitters responsible for secretion are unclear, but ACh appears to play a role. 
endocrine system (57-60). Immune cells are known to have receptors for several neurotransmitters and it appears that immune system mediators can activate the enteric nervous system. Thus, it is probable that the immune system interacts with the enteric nervous system to regulate intestinal water and electrolyte transport in both health and disease.

\section{Acknowledgments}

We wish to thank Ms. Kathy Holland and Dr. L. Kupper for statistical advice and Ms. Patricia Brown for secretarial assistance.

This work was supported by National Institutes of Health grants DK-15350, DK-34987, and DK-07463.

\section{References}

1. Rampton, D. S., and C. J. Hawkey. 1984. Prostaglandins and ulcerative colitis. Gut. 25:1399-1413.

2. Sharon, P., and W. F. Stenson. 1984. Enhanced synthesis of leukotriene $\mathrm{B}_{\mathbf{4}}$ by colonic mucosa in inflammatory bowel disease. Gastroenterology. 86:453-460.

3. Serafin, W. E., and K. F. Austen. 1987. Mediators of immediate hypersensitivity reactions. $N$. Engl. J. Med. 317:30-34.

4. Kimberg, D. V., M. Field, J. Johnson, A. Henderson, and E. Gershon. 1971. Stimulation of intestinal mucosal adenyl cyclase by cholera enterotoxin and prostaglandins. J. Clin. Invest. 50:1218-1230.

5. Al-Awqati, Q., and W. B. Greenough. 1972. Prostaglandins inhibit intestinal sodium transport. Nat. New Biol. 238:26-27.

6. Musch, M. W., R. J. Miller, M. Field, and M. I. Siegel. 1982. Stimulation of colonic secretion by lipoxygenase metabolites of arachidonic acid. Science (Wash. DC). 217:1255-1256.

7. Lawson, L. D., and D. W. Powell. 1987. Bradykinin-stimulated eicosanoid synthesis and secretion by rabbit ileal components. Am. J. Physiol. 252 (Gastrointest. Liver Physiol. 15).G783-G790.

8. Smith, G. S., G. Warhurst, and L. A. Turnberg. 1982. Synthesis and degradation of prostaglandin $\mathrm{E}_{2}$ in the epithelial and sub-epithelial layers of the rat intestine. Biochim. Biophys. Acta. 713:684-687.

9. Craven, P. A., and F. R. DeRubertis. 1986. Profiles of eicosanoid production by superficial and proliferative colonic epithelial cells and sub-epithelial colonic tissue. Prostaglandins. 32:387-399.

10. Goetzl, E. J. 1981. Oxygenation products of arachidonic acid as mediators of hypersensitivity and inflammation. Med. Clin. North Am. 65:809-828.

11. Lewis, R. A., and K. F. Austen. 1984. The biologically active leukotrienes. J. Clin. Invest. 73:889-897.

12. Binder, H. J. and C. L. Rawlins. 1973. Electrolyte transport across isolated large intestinal mucosa. Am. J. Physiol. 225:12321239.

13. Frizzell, R. A., M. J. Koch, and S. G. Schultz. 1976. Ion transport by rabbit colon. J. Membr. Biol. 27:297-316.

14. Andres, H., R. Bock, R. J. Bridges, W. Rummel, and J. Schreiner. 1985. Submucosal plexus and electrolyte transport across rat colonic mucosa. J. Physiol. (Lond.). 364:301-312.

15. Berschneider, H. M., H. Martens, and D. W. Powell. 1988. Effect of BW 942C, an enkephalinlike pentapeptide, on sodium and chloride transport in the rabbit ileum. Gastroenterology. 94:127-136.

16. Granstrom, E. and H. Kindahl. 1978. Radioimmunoassay of prostaglandins and thromboxanes. Adv. Prostaglandin Thromboxane Res. 5:119-210.

17. Pickard, R. N., J. C. Ludwig, and L. M. McManus. 1988. Platelet-activating factor. In Inflammation: Basic Principles and Clinical Correlates. J. I. Gallin, I. M. Goldstein, and R. Snyderman, editors. Raven Press, New York. 139-167.

18. Fox, C. C., A. M. Dvorak, S. P. Peters, A. Kagey-Sobotka, and L. M. Lichtenstein. 1985. Isolation and characterization of human intestinal mucosal mast cells. J. Immunol. 135:483-491.
19. Niedel, J. E., and P. Cuatrecasas. 1980. Formyl peptide chemotactic receptors of leukocytes and macrophages. In Current Topics in Cellular Regulation. B. L. Horecker and R. Stadtman, editors. Academic Press, Inc., New York. 17:137-170.

20. Barrett, T. A., M. W. Musch, and E. B. Chang. 1988. Chemotactic peptide (F-MET-LEU-PHE) effects on intestinal electrolyte transport: involvement of arachidonic acid metabolites. Gastroenterology. 94:A25. (Abstr.)

21. Hanglow, A. C., J. Bienenstock, N. Dyck, and M. H. Perdue. 1987. Effects of platelet-activating factor (PAF) on rat jejunal mucosa. Gastroenterology. 92:1424 (Abstr.)

22. Karayalcin, S. S., C. W. Sturbaum, M. U. Dixon, and D. W. Powell. 1988. Hydrogen peroxide is the reactive oxygen species (ROS) which stimulates colonic electrolyte secretion. Gastroenterology. 94:A216. (Abstr.)

23. Capron, A., J. P. Dessaint, M. Capron, M. Joseph, J. C. Ameisen and A. B. Tonnel. 1986. From parasites to allergy: a second receptor for IgE. Immunol. Today. 7:15-18.

24. Ehrenpreis, S. 1980. Prostaglandin as a modulator of acetylcholine release in guinea pig myenteric plexus. In Advances in Pharmacological Research and Practice. Proceedings of the Third Congress of the Hungarian Pharmacological Society, Budapest, 1979. E. S. Vizi, editor. Pergamon Press, Budapest, Hungary. 291-300.

25. Yagasaki, O., M. Takai, and I. Yanagiya. 1981. Acetylcholine release from the myenteric plexus of guinea-pig ileum by prostaglandin E $_{1}$. J. Pharm. Pharmacol. 33:521-525.

26. Gaion, R. M., and M. Trento. 1983. The role of prostacyclin in modulating cholinergic neurotransmission in guinea-pig ileum. $\mathrm{Br} . \mathrm{J}$. Pharmacol. 80:279-286.

27. Brunsson, I., A. Sjötlqvist, M. Jodal, and O. Lundgren. 1987. Mechanisms underlying the small intestinal fluid secretion caused by arachidonic acid, prostaglandin $E_{1}$ and prostaglandin $E_{2}$ in the rat in vivo. Acta Physiol. Scand. 130:633-642.

28. Diener, M., R. J. Bridges, S. F. Knobloch, and W. Rummel. 1988. Neuronally mediated and direct effects of prostaglandins on ion transport in rat colon descendens. Naunyn-Schmiedeberg's Arch. Pharmacol. 337:74-78.

29. Goerg, K. J., M. Roux, R. Wanitschke, K. H. Meyer zum Buschenfelde. 1986. Die bedeutung des meibnerschen plexus fur die sekretorische funktion der colonschleimhaut. Z. Gastroenterol. 24:70-78.

30. Powell, D. W. 1986. Ion and water transport in the intestine. In Physiology of Membrane Disorders. T. E. Andreoli, J. F. Hoffman, D. D. Fanestil, and S. G. Schultz, editors. Plenum Publishing Corp., New York. 559-596.

31. Castro, G. A. 1982. Immunological regulation of epithelial function. Am. J. Physiol. 243(Gastrointest. Liver Physiol. 6):G321G329.

32. Ishizaka, T., and K. Ishizaka. 1984. Activation of mast cells for mediator release through IgE receptors. Prog. Allergy. 34:188-235.

33. Sha'af, R. I., M. Volpi, and P. H. Naccache. 1985. Differences between the effects of f-met-leu-phe and leukotriene $B_{4}$ on phosphoinositide turnover and their relationship to calcium mobilization and protein kinase $\mathrm{c}$ activation. In Prostaglandins, Leukotriene $\mathrm{B}_{\mathbf{4}}$ and Lipoxins. J. M. Bailey, editor. Plenum Publishing Corp., New York. 241-250.

34. Elson, C. O., M. F. Kagnoff, C. Fiocchi, A. Dean Befus, and S. Targan. 1986. Intestinal immunity and inflammation: recent progress. Gastroenterology. 91:746-768.

35. Schwartz, L. B., and K. F. Austen. 1984. Structure and function of the chemical mediators of mast cells. Prog. Allergy. 34:271-321.

36. Granger, D. N., L. A. Hernandez, and M. B. Grisham. 1986. Reactive oxygen metabolites: mediators of cell injury in the digestive system. Viewpoints Dig. Dis. 18:13-16.

37. Cost, H., C. Gespach, and J. P. Abita. 1981. Effect of indomethacin on the binding of the chemotactic peptide formyl-met-leuphe on human polymorphonuclear leukocytes. FEBS (Fed. Eur. Biochem. Soc.) Lett. 132:85-88. 
38. Van Dyke, K., D. Peden, C. Van Dyke, G. Jones, V. Castranova, and J. Ma. 1982. Inhibition by nonsteroidal antiinflammatory drugs of luminol-dependent human-granulocyte chemiluminescence and $\left[{ }^{3} \mathrm{H}\right] \mathrm{FMLP}$ binding. Inflammation. 6:113-125.

39. Edeleson, H. S., H. B. Kaplan, H. M. Korchak, J. E. Smolen, and G. Weissmann. 1982. Dissociation by piroxicam of degranulation and superoxide anion generation from decrements in chlortetracycline fluorescence of activated human neutrophils. Biochem. Biophys. Res. Commun. 104:247-253.

40. Hardcastle, J., and P. T. Hardcastle. 1987. The secretory action of histamine in rat small intestine. J. Physiol. (Lond.). 388:521-532.

41. Bokoch, G. M., and P. W. Reed. 1980. Stimulation of arachidonic acid metabolism in the polymorphonuclear leukocyte by an N-formylated peptide. J. Biol. Chem. 255:10223-10226.

42. Smith, P. L., D. P. Montzka, G. P. McCafferty, M. A. Wasserman, and J. D. Fondacaro. 1988. Effect of sulfidopeptide leukotrienes $\mathrm{D}_{4}$ and $\mathrm{E}_{4}$ on ileal ion transport in vitro in the rat and rabbit. Am. J. Physiol. 255(Gastrointest. Liver Physiol. 18):175-183.

43. Smith, G., G. Warhurst, M. Lees, and L. Turnberg. 1987. Evidence that $\mathrm{PGE}_{2}$ stimulates intestinal epithelial cell adenylate cyclase by a receptor-mediated mechanism. Pig. Dis. Sci. 32:71-75.

44. Bukhave, K., and J. Rask-Madsen. 1980. Saturation kinetics applied to in vitro effects of low prostaglandin $E_{2}$ and $F_{2 \alpha}$ concentrations on ion transport across human jejunal mucosa. Gastroenterology. 78:32-42.

45. Buebler, E., K. Bukhave, and J. Rask-Madsen. 1986. Significance of calcium for the prostaglandin $\mathrm{E}_{2}$-mediated secretory response to 5-hydroxytryptamine in the small intestine of the rat in vivo. Gastroenterology. 90:1972-1977.

46. Browning, J. G., J. Hardcastle, P. T. Hardcastle, and P. A. Sanford. 1977. The role of acetylcholine in the regulation of ion transport by rat colon mucosa. J. Physiol. (Lond.). 272:737-754.

47. Zimmerman, T. W., and H. J. Binder. 1983. Effect of tetrodotoxin on cholinergic agonist-mediated colonic electrolyte transport. Am. J. Physiol. 244(Gastrointest. Liver Physiol. 7):G386-G391.

48. Musch, M. W., M. Field, R. J. Miller, and J. S. Stoff. 1987. Homologous desensitization to prostaglandins in rabbit ileum. Am.J. Physiol. 252(Gastrointest. Liver Physiol. 15):G120-G127.
49. Chang, E. B., N. S. Wang, and M. C. Rao. 1985. Phorbol ester stimulation of active anion secretion in intestine. Am. J. Physiol. 249(Cell Physiol. 18):C356-C361.

50. Donowitz, M., H. Y. Cheng, and G. W. G. Sharp. 1986. Effects of phorbol esters on sodium and chloride transport in rat colon. Am. J. Physiol: 251(Gastrointest. Liver Physiol. 14):G509-517.

51. Chang, E. B., N. S. Wang, and L. F. Mayer. 1987. Lynphokines stimulate intestinal secretion: possible role as initiators of arachidonic acid (AA) metabolism in IBD. Gastroenterology. 92:1342. (Abstr.)

52. Cuthbert, A. W., P. McLaughlan, and R. R. A. Coombs. 1983. Immediate hypersensitivity reaction to $\beta$-lactoglobulin in the epithelium lining the colon of guinea pigs fed cows' milk. Int. Arch. Allergy Appl. Immunol. 72:34-40.

53. Baird, A. W., R. R. A. Coombs, P. McLaughlan, and A. W. Cuthbert. 1984. Immediate hypersensitivity reactions to cow milk proteins in isolated epithelium from ileum of milk-drinking guineapigs: comparisons with colonic epithelia. Int. Arch. Allergy Appl. Immunol. 75:255-263.

54. Baird, A. W., A. W. Cuthbert, and F. L. Pearce. 1985. Immediate hypersensitivity reactions in epithelia from rats infected with $\mathrm{Nip}$ postrongylus brasiliensis. Br. J. Pharmacol. 85:787-795.

55. Perdue, M. H., and D. G. Gall. 1986. Intestinal anaphylaxis in the rat: jejunal response to in vitro antigen exposure. Am. J. Physiol. 250(Gastrointest. Liver Physiol. 13):G427-G431.

56. Castro, G. A., Y. Harari, and D. Russell. 1987. Mediators of anaphylaxis-induced ion transport changes in small intestine. Am. J. Physiol. 253(Gastrointest. Liver Physiol. 16):G540-G548.

57. Blalock, J. E., and E. M. Smith. 1985. A complete regulatory loop between the immune and neuroendocrine systems. Fed. Proc. 44:108-111.

58. O'Dorisio, M. S. 1986. Neuropeptides and gastrointestinal immunity. Am. J. Med. 81:74-82.

59. Morley, J. E., N. E. Kay, G. F. Solomon, and N. P. Plotnikoff. 1987. Neuropeptides: conductors of the immune orchestra. Life Sci. 41:527-544.

60. Bienenstock, J., M. Tomioka, H. Matsuda, R. H. Stead, G. Quinonez, G. T. Simon, M. D. Coughlin, and J. A. Denburg. 1987. The role of mast cells in inflammatory processes: evidence for nerve/ mast cell interactions. Int. Arch. Allergy Appl. Immunol. 82:238-243. 